\title{
ANTIBACTERIAL POTENTIAL AND PHYTOCHEMICAL SCREENING OF PHYSALIS ANGULATA AND SOLANUM VIRGIANUM
}

\author{
S.B. Gagare ${ }^{1 *}$, S.L. Chavan², A. B. Sagade ${ }^{3}$ \\ 1.Modern College of Arts Science and Commerce, Gk, Pune \\ snehal@moderncollegegk.org
}

2. New Arts Commerce and Science College, Ahmednagar, Maharashtra.

3. Jijamata College of Science and Arts, Ahmednagar, Maharashtra.

\begin{abstract}
:
Plants belonging to the Solanaceae family are commonly used in traditional medicine for the treatment of different ailments. This study aimed at evaluating antibacterial potential and phytochemical screening of Physalis angulata and Solanum virgianum. Solanum virgianum showed antibacterial activity against Escherichia coli, Proteus vulgaris, Staphylococcus aureusand Pseudomonas spp.Physalis angulata showed antibacterial activity against Escherichia coli, Staphylococcus aureusand Pseudomonas spp. The Plantspossesses secondary metabolites which are contributing towards the inhibition of bacterial growth.
\end{abstract}

Key words: - Physalis angulata, Solanum virgianum, Solanaceae,Antibacterial, Phytochemical.

\section{INTRODUCTION:}

\section{Introduction}

The family Solanaceae comprises 300 genera and 5000 species $^{1}$ are distributed in the subtropical, warm-temperate climatic regions of the world. Pradhan and Singh 2, (1999) recorded 5 genera and 10 wild and 4 cultivated species from Ahmednagar district. The plants of this family are neglected as weeds but they have compounds which are having economic, pharmaceutical, agriculture value ${ }^{3}$. Infectious diseases are responsible for 14 millionglobal deaths annually and amongst them, bacterial infections 4 are a major threat. The only solutionto this problem is use of antibiotics or chemicals. However, the increasing failure of chemotherapy and antibiotic resistance exhibited by bacterial pathogenshas prompted researchers for screening of plants fortheir antimicrobial activity 5 .
In today's age bioprospecting and exploring the neglected plant resources for their valuable bioactive potential is essentially important 6

Thus, there is an urgentneed to discover new antimicrobials for new andre - emerging bacterial diseases.

Solanum virginianum Linn. has various phytochemicals that are medically valuable and are important sources of pharmacological. It has antispermatogenic, hepatoprotective and anticancer properties ${ }^{7}$.

Physalis angulata Ltraditionally useful as diuretic, laxative, anti-inflammatory, antigonorrhoeic. It is useful in gastric disorders (8,9). All occur naturally as weeds in agricultural fields and waste places. Though they are named in the category of weeds, but are potential drug plants to cure human ailments ${ }^{10,24}$

Physalis angulata and Solanum virgianum are from the Solanaceae family, rich in secondary metabolites with specific pharmacological 
properties(11,12). ThePresent study focuses on Phytochemical screening and possible antibacterial activity of Solanum virgianum and Physalis angulata

\section{MATERIAL \& METHODS:}

Plant materials:Fresh leaf samples of selected plants viz. Solanum virginianum and Physalis angulata collected from wastelands and agricultural fields. The plants were identified with the help of Flora of Maharashtra 13 .

Plant extracts preparation: The freshly collected plant materials were washed, shadow dried and then dried in hot air oven at a temperature not more than $45^{\circ} \mathrm{C}$. The dried materials were coarsely powdered using an electric blender.

Extraction Methodology:For the extraction of crude bioactives, plant powder was initially diluted with water to sample ratio of 10:1 $(\mathrm{v} / \mathrm{w})$. The diluted plant sample was kept at room temperature undisturbed for $24 \mathrm{~h}$. Then, it was kept in the orbital shaker for next $48 \mathrm{~h}$. The concentrated extracts of the drugs were subjected to phytochemical tests for the detection of the presence or absence of the chemical constituents as per the standard procedures(14-18).

Preliminary phytochemical screening -

The preliminary phytochemical screening was performed by standard methods of Plant Analysis(19-20). Analysis of phenols, tannins, flavonoids, alkaloids, steroids, saponins, carbohydrates, glycosides, terpenoids, quinones was done.

\section{Antibacterial Activity}

The antibacterial effect of extracts of the plants was tested by 'agar well diffusion' method 21 . 24 hours old culture of test organisms was taken, $0.1 \mathrm{ml}$ of these suspensions was spread uniformly. Wells were made on the seeded plate with the help of a sterilized well borer of
$6 \mathrm{~mm}$ diameter. Wells were then filled with $25 \mu 1$ of the extracts and allowed to diffuse for 60 minutes in refrigerator at $4^{\circ} \mathrm{C}$. The plates were then incubated at $37^{\circ} \mathrm{C}$ for 24 hours. The zone of the clearance around each well after the incubation period, confirms the antimicrobial activity of the respective extract. Each experiment was carried out in triplicates. The clear zones formed around each well were indicative of the antibacterial activity of the fractions. Random measurements in $\mathrm{mm}$ of the inhibition zones around wells in agar medium were taken and analyzed statistically.

\section{RESULT \& DISCUSSION:}

Solanum virginianumand Physalisangulatawere screened for the presence of various Phytochemicals using the qualitative analysis. The results are mentioned in Table 1.

The phytochemical screening of the plants revealed the presence of compounds like Phenols, flavonoids, saponins, terpenoids, steroids, glycosides. They might act as allelochemicals and be released in the surrounding environment, through various processes in the form of leachates, root exudates and even residues of plant parts which in due course of time become allelopathic to associated native plants. The antibacterial activity of leaf extracts of Solanum virginianumand Physalisangulatawas tested against gram positive Staphylococcus aureus and gram-negative Escherichia coli, Proteus vulgaris, Pseudomonas spp.The results for antimicrobial activity are mentioned in figure 1 and 2.Agar well diffusion' method was used to find out antibacterial activities of selected plant species of Solanaceae family againstEscherichia coli, Proteus vulgaris, Staphylococcus aureusandPseudomonas spp. Inhibition zones were measured in $\mathrm{mm}$. Data obtained was statistically analyzed using Single factor ANOVA. 
The sensitivity of tested Gram-positive and Gram-negative bacteria to different extracts was variable. 'Solanum virginianum showed antibacterial activity against all the four bacterianamely Escherichia coli, Proteus vulgaris,Staphylococcus aureusand Pseudomonas spp., but the highest activity was shown against Pseudomonas spp. It showed inhibition zone of $7.33 \mathrm{~mm}$. Whereas of Physalis angulatashowed highest activity of $4 \mathrm{~mm}$ against Staphylococcus aureus. It has no activity against $P$. vulgaris.

The results are consistent with findings by Sateesh $\mathrm{P}$ et al.,12 in phytochemical analysis of Physalisangulta reveals presence of alkaloids, flavonoids, phenols.

The antibacterial activity can be attributed towards the phytochemicals like alkaloids, flavanoids and saponins present in the plants. The Studies done by Reddy and Reddy, 22 reported that the Solanum virginianum is one of the important medicinal herbs in Ayurveda. Their studies indicated that Solanum virginianum possesses antiasthmatic, hypoglycemic, hepatoprotective, antibacterial and insect repellant properties.

Donkor et al., (2012) compared the antimicrobial activity of zinc oxide ointment and $P$. angulatacrude fruit extracts against Pseudomonas aeruginosa and Staphylococcus aureus 23. The unformulated crude extract of plant fruit exhibited the highest inhibitory activity against $S$. aureus. These results showed that plant fruit extract is useful against the $S$. aureus infections.

\section{CONCLUSION}

The Phytochemical analysis suggests the presence of secondary metabolites which are medicinally important. The antibacterial activity reveals that a further detailed study of these neglected weeds of Ahmednagar district should be done to obtain natural antimicrobial agents.

Thus, the results of this study suggested that Solanaceae plants from Ahmednagar district could be a good natural source of chemopreventive and/or chemotherapeutic agents.

\section{REFERENCES:}

Willis, J C (1973): A Dictionary of the Flowering plants and Ferns 8th edition revised by $\mathrm{H}$ $\mathrm{K}$ hairy Shaw (Cambridge University Press). Pradhan, S.G. and Singh, N.P. (1999): Flora of Ahmednagar District, (Maharashtra) Published by Bishen Singh M. Pal Singh, Dehradun.Prakashan Publication, Pune. 105-108;593-597

R.G. Olmstead, L. Bohs, H. Abdel

Migid, E. Santiago-

alentin, V.F. Garcia, S.M. Collier (2008): A molecular phylogeny of the Solanaceae Taxon, 57:1159-1181

Walsh, C. (2003): Where will new antibiotics come from? Nat Rev Microbiol; 1:65-70.

Westh H, Zinn C.S, Rosdahl V.T. (2004): An international multicenter study of antimicrobial consumption and resistance in Staphylococcus aureus isolate from 15 hospitals in 14 countries. Microb Drug Resist; 10:169-76.

Gagare S. B. and Jadhav P. S. (2018): Hepatoprotective and Antibacterial Potential of Purified Active Components from Sesuvium portulacastrum extracts. Journal of Chemistry and Chemical Sciences, Vol.8(4). 756-763.

Poongothai, K. Ponmurugan, P.,Amed, K.S., Kumar, B.S. and Sheriff, S.A. (2011): Antihyperglycemic and antioxidant effects of Solanum xanthocarpumleaves(field grown and in vitro raised) extracts on alloxan 
induced diabetic rats 4(10):778-785 europepmc.org

Dash, B (1991): Materia Medica of Ayurveda based on Madanpala's Nighantu.B. Jain Publishers,New Delhi.P. 780.

Daya, L. Chotani and H.V. Vaghasiya. (2012): A Phyto-pharmacological overview on Physalis angulataL.Indian J. of Nat.Products and resources 3(4):477-482.

Akintayo L., Ogundajo Atikueke S., Akpome NimotaA., Tijani.(2015):Chemical constituent of the leaf essential oil of Physalis angulata L.Asian journal of applied sciences 3(4):652-55 http;//www worldwidejournals.com

Lin, R.Y.; Wang, H.B.; Guo, X.K.; Ye, C.Y.; He, H.B.; Zhou, Y. and Lin, W.X. (2011): Impact of applied phenolic acids on the microbes, enzymes and available nutrients in paddy soils.Allelopathy Journal 28 (2):225-236.

Sateesh P, Porika R and Mamidala, E. (2014): Phytochemical analysis and in vitro antidiabetic activities of Physalisangulata fruit extracts. Phytochemical Analysis and In vitro Antidiabetic NJIRM 2014; Vol. 5(2). 34-38.

Singh, N.P., Lakshiminarasimhan, Karthikeyan S., Prasanna P.V. (2001) : Flora of Maharashtra State Vol I and II Botanical Survey of India.

Harborne, J. M. (1973): Phytochemical Methods, Chapman and Hall, London.

Harborne, J. B. (2005): Phytochemical methods. A Guide to modern techniques of plant analysis, 3rd edition, Springer (India) Pvt. Ltd., New Delhi. Pages: 4 -7, 9-12, 45, 119, $125,135$.
Kokate, C. K. and A. P. Purohit. (2006): Pharmacognosy. 34th edition, Nirali publications.

Raaman, N. (2006): Phytochemical Techniques, New India Publishing Agency.

Vogel, A.J. (1975): A text book of practical organic chemistry. 3rdedition, English Language Book Society \& Longman Gr. Ltd. volatiles. South African Journal of Botany 76: 612-631.

Gibbs, R.D. (1974):Chemotaxonomy of flowering plants, McGill queen's university press, Montreal. 523-619.

Peach, K. and M. V. Tracey. (1979): Modern Methods of Plant Analysis. Narosa Publishing House, New Delhi-III. Pages: 471, 627, 658.

Madhu, K.; Vanisree, R. and Devi, Y.P. (2015) : In vitro evaluation of antibacterial activity of leaf and flower extracts of Parthenium hysterophorus Biolife. 3(4): 838-842 www. biolifejournal.com

Reddy, N.M. and Reddy, R.N. (2014): Solanum xanthocarpum chemical constituents and medicinal properties: A review. Scholars Academic J. Of Pharmacy (SASP) 3(2):14849. Semantischolor.org

Donker A, Glover R, Boateng J, Gakpo V. (2012):Antibacterial activity of the fruit extract of Physalis angulata and its formulation. Journal of Medical and Biomedical sciences 2012;1(4): 21-26.

Gogoi, Pronob and M. Islam. (2012): Phytochemical screening of Solanum nigrum L and S. myriacanthus Dunal from Districts of Upper Assam, India. IOSR Journal of Pharmacy. 2, pp 455-459. 
Table1: Qualitative phytochemical analysis of Physalis angulataand Solanum virginianum

\begin{tabular}{|l|l|l|}
\hline Phytochemical compound & Physalisangulata & Solanum virginianum \\
\hline Alkaloids & + & - \\
\hline Flavonoids & + & + \\
\hline Phenols & + & + \\
\hline Saponins & + & + \\
\hline Sterols & + & + \\
\hline Tannins & - & + \\
\hline Carbohydrate & + & + \\
\hline Cardiac glycosides & + & + \\
\hline Terpenoids & + & + \\
\hline Quinones & + & + \\
\hline “+” present “_" absent & & \\
\hline
\end{tabular}

"+" present "_" absent

Figure 1: Antibacterial activity of leaf extracts of Solanum virginianum

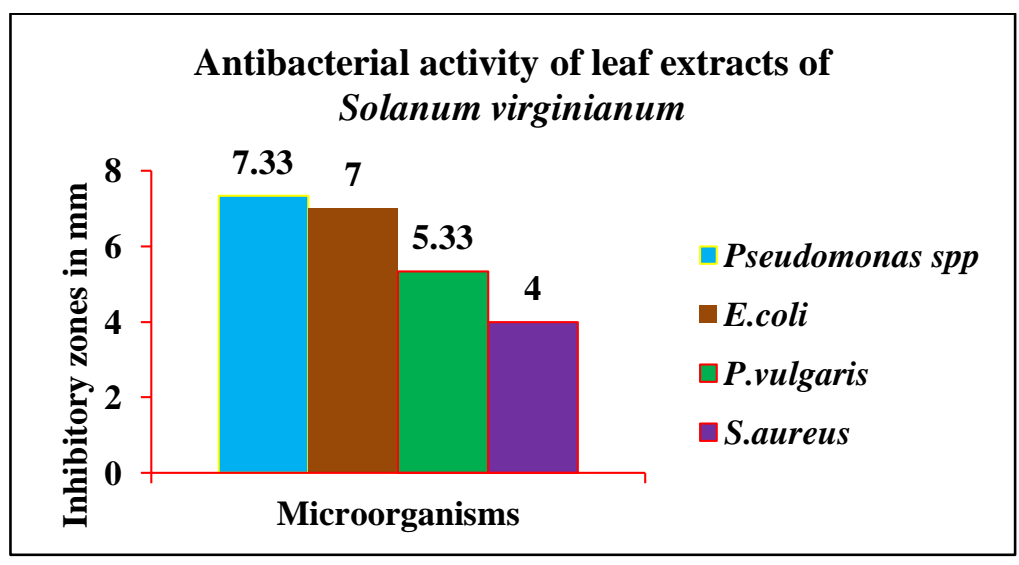

Figure 2: Antibacterial activity of leaf extracts of Physalis angulata

\begin{tabular}{|r|r|r|}
\hline \multicolumn{4}{|c|}{$\begin{array}{c}\text { Antibacterial activity of of leaf extracts of } \\
\text { Physalis angulata }\end{array}$} \\
\\
4.5 \\
4 \\
2
\end{tabular}

